\title{
OPTIMASI PENAMBAHAN TEPUNG KOMPOSIT TERIGU, BEKATUL, DAN KACANG MERAH TERHADAP KUALITAS KIMIA COOKIES
}

\author{
Intan Permata Hati, Bhakti Etza Setiani*, Valentinus Priyo Bintoro
}

\begin{abstract}
${ }^{1}$ Program Studi Teknologi Pangan, Departemen Pertanian, Fakultas Peternakan dan Pertanian, Universitas Diponegoro. Jl. Prof. Sudarto SH, Tembalang, Semarang, Jawa Tengah 50275, Indonesia. *Penulis Penanggungjawab: etz_16@yahoo.com
\end{abstract}

\begin{abstract}
Background: Many people like biscuit because it is tasty and practical, but biscuit that is distributed contains low fiber and protein. Therefore, local ingredients are needed to increase fiber and protein cookies. Rice bran and red beans are local ingredients that can be used as an alternative raw material for cookies, but these local ingredients have a short shelf life, so they other ingredients.

Objectives: This research aimed to know the effect of cookies from composite flour (wheat, bran, and red beans) on chemical quality cookies. The quality of the chemicals in cookies discussed was crude fiber, protein, ash, and antioxidant activity.

Methods: The experimental design used 4 level of Wheat Flour: BKM Flour, T1 90\%: 10\% (w/w), T2 85\%: 15\% (w/w), T3 80\%: $20 \%(w / w)$, and T4 $75 \%: 25 \%(w / w)$ with 5 replications. Crude fiber, protein, and ash data were analyzed with ANOVA $(p<0.05)$, if there is an effect, then continued with DMRT, while the antioxidant activity data were analyzed descriptively.

Results: The level of crude fiber cookies in the T4 treatment was 17.92\%, the highest protein content was in the T4 treatment at $10.65 \%$, the highest ash content in the T4 treatment was $2.26 \%$, and the highest level of antioxidant activity was in the T4 treatment amounted to $81.16 \%$

Conclusion: The results of the research that showed the best cookies were T4 (Wheat Flour 75\% : Flour BKM 25\%) cookies from composite flour (wheat, bran, and red bean) because it was able to increase crude fiber, protein, ash, and antioxidant activity. However, the ash content of cookies was not meet the quality requirements of cookies. Subsequent research to add other ingredients to ask for colors in cookies and to test antioxidant activity after making cookie products.
\end{abstract}

Keywords: rice bran; red beans; chemical quality cookies

\begin{abstract}
ABSTRAK
Latar Belakang: Cookies banyak disukai berbagai kalangan karena rasanya yang manis dan praktis, namun cookies yang beredar di pasaran mengandung serat dan protein rendah. Maka dari itu, dibutuhkan bahan lokal untuk meningkatkan serat dan protein cookies. Bekatul dan kacang merah merupakan bahan lokal yang dapat dijadikan alternatif sebagai bahan baku cookies, namun bahan lokal tersebut memiliki masa simpan pendek, sehingga perlu dijadikan bahan setengah jadi, yaitu tepung.

Tujuan: Penelitian ini bertujuan untuk mengetahui pengaruh penambahan tepung komposit terigu, bekatul, dan kacang merah pada kualitas kimia cookies. Kualitas kimia pada cookies yang diamati adalah serat kasar, protein, abu, dan aktivitas antioksidan.

Metode: Rancangan percobaan menggunakan 4 perlakuan Terigu : Tepung BKM (Bekatul Kacang Merah), yaitu perlakuan 1 (T1) 90\%:10\% (b/b), perlakuan 2 (T2) 85\%:15\% (b/b), perlakuan 3 (T3) 80\%:20\% (b/b), dan perlakuan 4 (T4) 75\%:25\% (b/b). masing-masing perlakuan dilakukan 5 kali ulangan. Data serat kasar, protein, dan abu dianalisis dengan ANOVA $(p<0,05)$ jika terdapat pengaruh, maka dilanjutkan dengan DMRT, sedangkan data aktivitas antioksidan dianalisis secara deskriptif dengan melihat rerata.

Hasil: Kadar serat kasar cookies terdapat pada perlakuan T4 sebesar 17,92\%, kadar protein tertinggi terdapat pada perlakuan T4 sebesar 10,65\%, kadar abu tertinggi terdapat pada perlakuan T4 sebesar 2,26\%, dan kadar aktivitas antioksidan tertinggi terdapat pada perlakuan T4 sebesar $81,16 \%$.

Kesimpulan: Hasil penelitian menunjukkan bahwa perlakuan terbaik cookies adalah perlakuan T4 (Tepung terigu $75 \%$ : Tepung BKM 25\%) cookies tepung komposit terigu, bekatul, dan kacang merah karena mampu meningkatkan serat kasar, protein, abu, dan aktivitas antioksidan. Namun, kadar abu cookies belum memenuhi syarat mutu cookies. Penelitian selanjutnya disarankan untuk menambahkan bahan lain untuk menutupi warna gelap pada cookies yang dikarenakan cookies penelitian ini berwarna hitam, serta melakukan pengujian aktivitas antioksidan setelah pembuatan produk cookies.
\end{abstract}

Kata kunci : bekatul; kacang merah; kualitas kimia cookies 


\section{PENDAHULUAN}

Cookies banyak beredar di pasaran dan digemari berbagai kalangan karena rasanya yang manis dan praktis. Bahan dasar pembuatan cookies adalah tepung terigu yang dicampur dengan bahan pendukung, kemudian diproses dengan pemanggangan ${ }^{7}$. Perkembangan konsumsi rata-rata kue kering di Indonesia pada tahun 2011 - 2015 lebih tinggi dibandingkan konsumsi kue basah, yaitu $24,22 \%$, sedangkan kue basah sebesar $17,78 \%{ }^{11}$. Namun, saat ini cookies yang dikonsumsi masyarakat dan beredar di pasaran memiliki kandungan serat dan protein rendah serta kalori yang tinggi, sehingga diperlukan penambahan bahan lokal tinggi serat dan protein dalam pembuatan cookies.

Kandungan serat pada cookies dapat ditingkatkan melalui penggunaan salah satu bahan lokal, seperti bekatul. Indonesia memiliki ketersediaan bekatul yang sangat melimpah. Indonesia dapat memproduksi bekatul dari proses penggilingan padi mencapai $4-6$ juta ton per tahun. Bekatul memiliki serat kasar yang tinggi, selain itu mengandung protein, asam lemak bebas, mineral, serta kaya akan vitamin B1. Selain itu, bekatul juga memiliki 3 senyawa antioksidan yang mampu menangkal radikal bebas dan lipid peroksidasi, yaitu tokoferol, tokotrienol, dan orizanol. Namun, dalam pemanfaatannya bekatul hanya dijadikan pakan ternak, padahal bekatul memiliki potensi cukup besar apabila dimanfaatkan secara optimal. Agar pemanfaatan bekatul dapat tercapai, maka diperlukan cara untuk memperpanjang masa simpan bekatul. Tepung bekatul dapat menjadi salah satu alternatif dalam pemanfaatannya karena mudah dicampur dengan bahan lain.

Salah satu bahan lokal yang memiliki kandungan protein tinggi adalah kacang merah.
Produksi kacang merah di Indonesia pada tahun 2014 mencapai 100.316 ton $^{3}$. Kacang merah merupakan sumber protein yang sangat bermanfaat bagi tubuh karena dapat meregenerasi sel-sel dalam tubuh yang rusak. Kandungan pati dalam kacang merah juga dapat digunakan sebagai sumber energi. Kulit kacang merah mengandung senyawa antioksidan berupa antosianin yang dapat mencegah berbagai penyakit. Selain itu, kacang merah mudah ditemukan di pasar tradisional dengan harga terjangkau. Namun, kacang merah segar memiliki umur simpan pendek dalam bentuk mentah, sehingga diperlukan cara untuk memperpanjang masa simpannya. Salah satunya dengan mengolahnya menjadi tepung.

Berdasarkan latar belakang tersebut, penggunaan tepung bekatul dan tepung kacang merah dapat dijadikan alternatif sebagai bahan baku cookies tinggi serat dan protein. Cookies tersebut diharapkan dapat dijadikan sebagai alternatif camilan sehat untuk masyarakat, karena memiliki serat dan protein yang tinggi.

\section{METODE}

Penelitian yang dilakukan termasuk dalam bidang ilmu Food Production. Penelitian ini dilaksanakan pada bulan Desember 2019 - Januari 2020 di Laboratorium Rekayasa Pangan dan Hasil Pertanian, Laboratorium Kimia dan Gizi Pangan, Laboratorium Fisiologi dan Pemuliaan Tanaman, Laboratorium Ilmu dan Nutrisi Pakan, serta Laboratorium Terpadu, Universitas Diponegoro, Semarang. Penelitian ini merupakan penelitian eksperimental satu faktor dengan 4 taraf perlakuan dengan 5 kali pengulangan. Taraf perlakuan dalam penelitian ini dapat dilihat pada Tabel 1 .

Tabel 1. Taraf Perlakuan Cookies Tepung Komposit Terigu, Bekatul, dan Kacang Merah

\begin{tabular}{lcccc}
\hline \multicolumn{1}{c}{ Bahan (g) } & T1 & T2 & T3 & T4 \\
\hline Tepung terigu & 90 & 85 & 80 & 75 \\
Tepung BKM (Bekatul Kacang Merah) & 10 & 15 & 20 & 25 \\
Margarin & 40 & 40 & 40 & 40 \\
Gula halus & 60 & 60 & 60 & 60 \\
Garam & 0,5 & 0,5 & 0,5 & 0,5 \\
Susu skim & 5 & 5 & 16 & 5 \\
Kuning telur & 16 & 16 & 5 & 16 \\
Air & 5 & 5 & 0,5 & 5 \\
Baking soda & 0,5 & 0,5 & 0,5 \\
\hline T1 (Perlakuan 1) : tepung terigu 90\% : tepung BKM 10\% ; T2 (Perlakuan 2) : tepung terigu 85\% : tepung BKM 15\% ; T3 (Perlakuan 3) : tepung
\end{tabular}
terigu $80 \%$ : tepung BKM 20\%; T4 (Perlakuan 4) : tepung terigu $75 \%$ : tepung BKM $25 \%$

Pembuatan cookies dilakukan dengan pencampuran, pengadonan, pembentukan, dan pemanggangan. Tepung bekatul yang digunakan adalah hasil penepungan bekatul yang berasal dari Meteseh, Semarang dan dibuat berdasarkan Mulyani et al. yaitu bekatul diayak 60 mesh dan disangrai selama $3-7$ menit pada suhu $70^{\circ} \mathrm{C}-90^{\circ} \mathrm{C}$ daun pandan, kemudian dilakukan pengayakan 80 mesh $^{18}$. Tepung kacang merah yang digunakan adalah hasil penepungan kacang merah yang berasal dari Pasar 
Damar, Semarang dan dibuat berdasarkan Irawan et al. yaitu kacang merah direndam 48 jam, dicuci, ditiriskan, dan dikeringkan dengan cabinet drier pada suhu $60^{\circ} \mathrm{C}$ selama \pm 24 jam, kemudian disangrai selama 5 menit pada suhu $80-90^{\circ} \mathrm{C}$, ditepungkan, dan diayak 80 mesh $^{9}$. Tepung BKM dibuat dengan pencampuran tepung bekatul dan tepung kacang merah dengan rasio $1: 1$. Parameter yang diujikan pada penelitian ini, antara lain kadar serat kasar dengan metode ekstraksi dengan asam dan basa ${ }^{4}$, kadar protein dengan metode Kjeldahl ${ }^{13}$, kadar abu dengan metode tanur ${ }^{4}$, dan aktivitas antioksidan ${ }^{10}$ dengan metode spektrofotometri.

Data hasil analisis uji serat kasar, protein dan abu cookies dianalisis dengan metode Analysis of Variance (ANOVA) $(\mathrm{p}<0,05)$ menggunakan perangkat lunak pengolah data SPSS versi 16.0 untuk mengetahui ada tidaknya pengaruh antara perlakuan. Apabila terdapat pengaruh, maka dilanjutkan dengan Duncan Multiple Range Test (DMRT). Hasil analisis uji aktivitas antioksidan dianalisis secara deskriptif dengan membaca rerata.

\section{HASIL \\ Kadar Serat Kasar}

Hasil analisis kadar serat kasar, protein, dan kadar abu cookies tepung komposit terigu, bekatul, dan kacang merah disajikan pada Tabel 2. Berdasarkan hasil analisis yang diperoleh pada Tabel 2 menunjukkan bahwa kadar serat kasar cookies dari tepung komposit terigu, bekatul, dan kacang merah tertinggi terdapat pada perlakuan T4 (tepung terigu 75\% : tepung BKM 25\%) sebesar $17,92 \%$, sedangkan kadar serat kasar terendah terdapat pada perlakuan T1 (tepung terigu 90\% : tepung BKM 10\%) sebesar 14,86\%.

Tabel 2. Hasil Analisis Kadar Serat Kasar, Protein, dan Kadar Abu Cookies Tepung Komposit Terigu, Bekatul, dan Kacang Merah

\begin{tabular}{cccc}
\hline Perlakuan & Serat Kasar (\%) & Protein (\%) & Kadar Abu (\%) \\
\hline TI & $14,86 \pm 1,54^{\mathrm{a}}$ & $4,21 \pm 1,87^{\mathrm{a}}$ & $1,78 \pm 0,19^{\mathrm{a}}$ \\
T2 & $16,07 \pm 0,91^{\mathrm{ab}}$ & $6,07 \pm 2,33^{\mathrm{ab}}$ & $1,86 \pm 0,18^{\mathrm{a}}$ \\
T3 & $17,12 \pm 1,97^{\mathrm{b}}$ & $7,33 \pm 2,65^{\mathrm{b}}$ & $2,12 \pm 0,20^{\mathrm{b}}$ \\
T4 & $17,92 \pm 1,79^{\mathrm{b}}$ & $10,65 \pm 1,48^{\mathrm{c}}$ & $2,26 \pm 0,17^{\mathrm{b}}$ \\
\hline
\end{tabular}

Keterangan: -Superscipt huruf kecil yang berbeda pada kolom yang sama menunjukkan perbedaan nyata $(\mathrm{p}<0,05)$. T1 $=90 \%: 10 \% ; \mathrm{T} 2=85 \%: 15 \%$; $\mathrm{T} 3=80 \%: 20 \% ; \mathrm{T} 4=85 \%: 25 \%$.

Kadar protein cookies dari tepung komposit terigu, bekatul, dan kacang merah yang tertinggi terdapat pada perlakuan T4 (tepung terigu $75 \%$ : tepung BKM 25\%) sebesar $10,65 \%$, sedangkan kadar protein terendah terdapat pada perlakuan $\mathrm{T} 1$ (tepung terigu 90\% : tepung BKM 10\%) sebesar $4,21 \%$.

Kadar abu cookies dari tepung komposit terigu, bekatul, dan kacang merah yang tertinggi terdapat pada perlakuan T4 (tepung terigu $75 \%$ : tepung BKM 25\%) sebesar 2,26\%, sedangkan kadar abu terendah terdapat pada perlakuan T1 (tepung terigu $90 \%$ : tepung BKM $10 \%$ ) sebesar $1,78 \%$.

\section{Aktivitas Antioksidan}

Hasil analisis aktivitas antioksidan cookies tepung komposit terigu, bekatul, dan kacang merah disajikan pada Gambar 1. Berdasarkan hasil analisis yang diperoleh pada Ilustrasi 1 menunjukkan bahwa kadar protein cookies dari tepung komposit terigu, bekatul, dan kacang merah yang tertinggi terdapat pada perlakuan T4 (tepung terigu $75 \%$ : tepung BKM 25\%) sebesar 81,16\%, sedangkan kadar protein terendah terdapat pada perlakuan T0 (tepung terigu $100 \%$ ) sebesar $62,28 \%$.

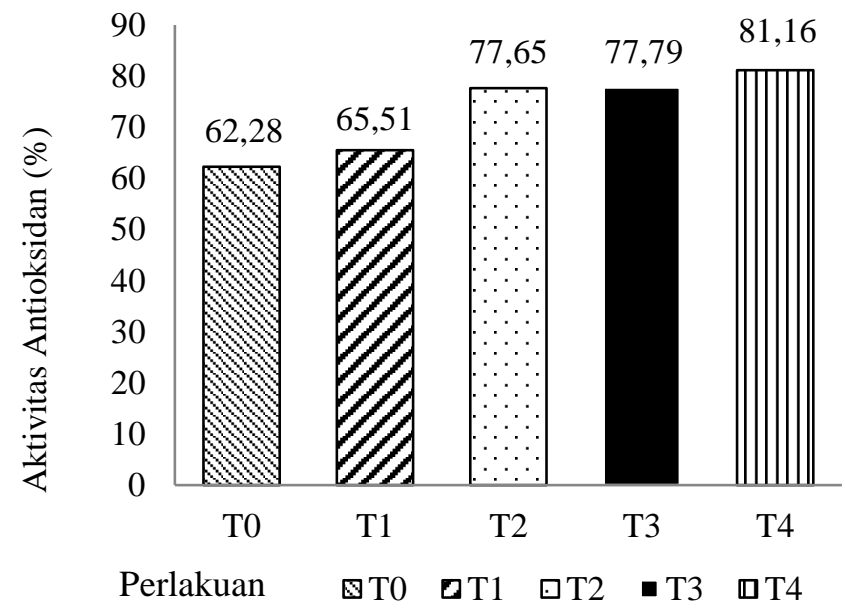

Gambar 1. Histogram Aktivitas Antioksidan Cookies

Tepung Komposit Terigu, Bekatul, dan Kacang Merah

\section{PEMBAHASAN}

Kadar Serat Kasar

Penambahan tepung komposit terigu, bekatul, dan kacang merah berpengaruh terhadap kadar serat kasar cookies. Semakin tinggi penggunaan tepung bekatul, maka kadar serat kasar dalam cookies semakin tinggi. Hal ini didukung oleh penelitian Pradipta dan Putri yang menyatakan bahwa peningkatan presentase substitusi tepung bekatul 
dalam tepung terigu pada biskuit mampu meningkatkan serat $\operatorname{kasar}^{19}$. Bekatul merupakan bagian kulit padi yang memiliki serat tinggi yang sebagian besar terdiri dari karbohidrat, antara lain selulosa $(8,7-11,4 \%)$, hemiselulosa $(9,6-12,8 \%)$, dan lignin ${ }^{15}$.

Tepung kacang merah membantu peningkatan kadar serat kasar pada cookies karena lebih tinggi dibandingkan dengan kadar serat tepung terigu, yaitu sebesar 3,93\%. Kadar serat kasar tepung kacang merah tidak berbeda jauh dengan kadar serat kasar kacang merah, yaitu 4\% karena dalam proses pembuatan tepung kacang merah tidak dilakukan pengupasan kulit kacang merah. Dinding tanaman terdapat kadar serat yang tinggi ${ }^{6}$. Dinding tersebut terdiri dari 2 dinding, dinding pertama terdiri dari selulosa yang merupakan pembungkus sel dan dinding kedua merupakan dinding yang terdiri dari selulosa dan non selulosa.

Kadar serat kasar cookies berdasarkan (SNI) 01-2973-2011, maksimum 0,5\% (db). Dengan demikian, perlakuan T1, T2, T3, dan T4 cookies tepung komposit terigu, bekatul, dan kacang merah melebihi syarat mutu cookies. Namun, di dalam penelitian ini, pembuatan cookies tepung komposit terigu, bekatul, dan kacang merah bertujuan untuk meningkatkan serat kasar. Suatu produk dapat disebut sebagai pangan tinggi serat apabila memiliki serat sebesar $6 \mathrm{~g}$ per $100 \mathrm{~g}^{2}$. Produk cookies tepung komposit terigu, bekatul, dan kacang merah dapat dikatakan sebagai produk tinggi serat karena dalam 100 g nya memiliki serat kasar berkisar 14,86 $17,92 \%$.

\section{Kadar Protein}

Penambahan tepung komposit terigu, bekatul, dan kacang merah berpengaruh terhadap kadar protein cookies. Tingginya kadar protein pada cookies perlakuan T4 dibandingkan perlakuan T1, T2, dan T3 disebabkan oleh konsentrasi tepung kacang merah dan bekatul yang diberikan lebih tinggi. Menurut Tamrin dan Pujilestari yang menyatakan bahwa untuk meningkatkan kadar protein dalam produk pangan dapat ditambahkan tepung kacang merah untuk mendampingi tepung lain yang memiliki kadar protein yang rendah ${ }^{22}$. Tepung kacang merah memiliki kadar protein yang lebih tinggi dibandingkan tepung terigu, yaitu sebesar $19,48 \%$, sedangkan kandungan protein tepung terigu sebesar $7-9 \%$. Tepung bekatul juga memiliki kandungan protein yang lebih tinggi dari terigu, yaitu $10,41 \%$, sehingga pemberian tepung bekatul pada cookies mampu meningkatkan kadar protein cookies. Menurut Liandani dan Zubaidah penambahan tepung bekatul dalam mie instan dapat meningkatkan kadar protein dibandingkan dengan tepung terigu karena bekatul memiliki protein sebesar $10-15 \%^{14}$.

Kadar protein cookies berdasarkan (SNI) 012973-2011, minimum 6\% (db). Dengan demikian, perlakuan T1 cookies dari tepung komposit terigu, bekatul, dan kacang merah tidak memenuhi syarat mutu cookies, sedangkan perlakuan T2, T3, dan T4 cookies dari tepung komposit terigu, bekatul, dan kacang merah memenuhi syarat mutu cookies. Perlakuan T1 tidak memenuhi syarat SNI 01-29732011 dapat dikarenakan adanya penggunaan tepung bekatul dan tepung kacang merah yang lebih sedikit dibandingkan perlakuan T2, T3, dan T4.

\section{Kadar Abu}

Penambahan tepung komposit terigu, bekatul, dan kacang merah berpengaruh terhadap kadar abu cookies. Tepung bekatul dan tepung kacang merah memiliki kadar abu yang lebih tinggi dibandingkan tepung terigu. tepung bekatul memiliki kadar abu berkisar $5-6 \%$, sedangkan tepung terigu hanya memiliki kadar abu sebesar $0,52 \%{ }^{17}$. Tepung kacang merah organik memiliki kadar abu yang lebih tinggi dibandingkan tepung terigu, yaitu sebesar $2,75 \%{ }^{1}$.

Kadar abu yang tinggi dalam tepung bekatul dan tepung kacang merah disebabkan besarnya mineral dalam tepung tersebut, sehingga semakin tinggi tepung bekatul dan tepung kacang merah yang digunakan maka semakin tinggi kadar abu yang dihasilkan. Selain itu, kadar abu juga dipengaruhi oleh bahan penunjang yang digunakan dalam proses pembuatan adonan cookies ${ }^{9}$. Bahan penunjang yang digunakan, antara lain susu skim, margarine, garam, telur, dan baking soda.

Kadar abu cookies berdasarkan (SNI) 01-29732011, maksimal 1,5\% (db). Dengan demikian, kadar abu cookies dari tepung komposit terigu, bekatul, dan kacang merah berada di atas atau tidak memenuhi kadar maksimal syarat mutu cookies. Kadar abu yang tinggi pada cookies akan mengakibatkan warna gelap pada produk yang dihasilkan. Kadar abu produk pangan menunjukkan adanya mineral di dalam produk tersebut yang dapat melemahkan struktur jaringan gluten yang terbentuk di dalam adonan, jika kadar abu produk semakin tinggi, daya tahan adonan terhadap pengembangan akan semakin menurun ${ }^{21}$

\section{Aktivitas Antioksidan}

Perlakuan T4 cookies memiliki aktivitas antioksidan tertinggi karena memiliki presentase tepung bekatul dan tepung kacang merah yang lebih tinggi dibandingkan perlakuan lain. Tepung bekatul dapat meningkatkan aktivitas antioksidan dalam cookies karena bekatul memiliki fraksi minyak yang mengandung antioksidan, antara lain $\gamma$-oryzanol, tokotrienol, dan tokoferol. Minyak bekatul memiliki aktivitas antioksidan sebesar 46,798 - 47,290\% ${ }^{20}$. 
Pembuatan tepung bekatul dalam penelitian ini meliputi proses penghilangan enzim lipase yang mampu mempertahankan nutrisi dalam tepung bekatul, salah satunya adalah antioksidan.

Peningkatan presentase tepung kacang merah juga dapat meningkatkan aktivitas antioksidan cookies karena tepung kacang merah memiliki aktivitas antioksidan cukup tinggi. Hal ini sesuai dengan penelitian Wahjuningsih et al. yang menyatakan bahwa seiring meningkatnya presentase tepung kacang merah pada sereal tepung beras merah aktivitas antioksidan semakin meningkat ${ }^{23}$. Tepung kacang merah memiliki aktivitas antioksidan sebesar $29,50 \%{ }^{8}$.

Perlakuan T0 cookies memiliki aktivitas antioksidan terendah karena tepung terigu memiliki aktivitas antioksidan yang lebih rendah dibandingkan tepung bekatul dan tepung kacang merah, yaitu sebesar $28,0 \%$. Tepung terigu memiliki aktivitas antioksidan yang lebih rendah dibandingkan tepung bekatul dan tepung kacang merah, namun aktivitas antioksidan cookies perlakuan T0 termasuk memiliki aktivitas antioksidan yang tinggi. Sebuah studi menyatakan bahwa aktivitas antioksidan cookies tepung terigu $100 \%$ memiliki aktivitas antioksidan yang tidak jauh berbeda dengan perlakuan kontrol dalam penelitian ini. Studi yang dilakukan oleh Kurniawan et al. menunjukan bahwa perlakuan $100 \%$ tepung terigu pada cookies memiliki aktivitas antioksidan sebesar $68,78 \%{ }^{12}$. Suhu panggang dan waktu panggang roti memungkinkan adanya pelepasan senyawa ikatan fenol tidak larut yang terkonjugasi yang dapat meningkatkan aktivitas antioksidan ${ }^{16}$.

\section{SIMPULAN}

Berdasarkan penelitian yang telah dilakukan dapat disimpulkan bahwa perlakuan terbaik, yaitu cookies tepung komposit terigu, bekatul, dan kacang merah perlakuan $\mathrm{T} 4$ (tepung terigu $75 \%$ : tepung BKM 25\%). Tepung bekatul dan tepung kacang merah mampu meningkatkan serat kasar, protein, abu, dan aktivitas antioksidan, namun untuk kandungan abu dalam cookies tepung komposit terigu, bekatul, dan kacang merah masih diluar standar yang disyaratkan.

Berdasarkan penelitian yang telah dilakukan disarankan untuk menambahkan bahan lain untuk menutupi warna gelap dari cookies yang dihasilkan akibat kandungan abu pada cookies yang tinggi, sehingga cookies berwarna hitam. Penggunaan presentase tepung BKM di level rendah, yaitu $<25 \%$ direkomendasikan untuk penelitian selanjutnya, sehingga seluruh parameter kualitas cookies sesuai dengan SNI yang telah ditetapkan.

\section{DAFTAR PUSTAKA}

1. Astuti SD, Andarwulan N, Hariyadi P, Agustia FC. Formulasi dan karakterisasi cake berbasis tepung komposit organik kacang merah, kedelai, dan jagung. Jurnal Aplikasi Teknologi Pangan. 2014;3(2):54-59.

2. Badan Pengawas Obat dan Makanan Republik Indonesia. Pengawasan Klaim pada Label dan Iklan Pangan Olahan. Jakarta: BPOM. 2016.

3. Badan Pusat Statistik. Produksi Tanaman Sayuran dan Buah-Buahan Semusim Jawa Tengah 2018. [Internet]. [cited 2017 Agustus 27]. Available from: https://jateng.bps.go.id/statictable/2017/02/24/1 447/produksi-tanaman-sayuran-dan-buahbuahan-semusim-jawa-tengah-2010-2015.html.

4. Badan Standarisasi Nasional. SNI 01-28911992. Cara Uji Makanan dan Minuman. Jakarta: Dewan Standarisasi Indonesia. 1992.

5. Badan Standarisasi Nasional. SNI 01-28732011. Biskuit. Jakarta: Dewan Standarisasi Indonesia. 2011.

6. Beck ME. Ilmu Gizi dan Diet, Hubungannya dengan Penyakit-Penyakit untuk Perawat \& Dokter. Yogyakarta: Andi. 2011.

7. Delima D. Pengaruh substitusi tepung biji ketapang (Terminalia cattapa L) terhadap kualitas cookies. Food Science and Culinary Education Journal. 2013;2(2):9-15.

8. Fauziyah A, Marliyati SA, Kustiyah L. Substitusi tepung kacang merah meningkatkan kandungan gizi, serat pangan, dan kapasitas antioksidan beras analog sorgum. Jurnal Gizi Pangan. 2017;12(2):147-152.

9. Irawan FM, Ishartani D, Affandi DR. Pemanfaatan tepung umbi garut (Maranta arundinacea L.) sebagai pengganti terigu dalam pembuatan biskuit tinggi energi protein dengan penambahan tepung kacang merah (Phaseolus vulgaris L). Jurnal Teknosains Pangan. 2014;3(1):3-14.

10. Irmawati I, Ansharullah A, Baco AR. Pengaruh formulasi roti tawar berbasis mocaf dan ubi jalar ungu (Ipomoea batatas L.) terhadap nilai proksimat dan aktivitas antioksidan. Jurnal Sains dan Teknologi Pangan. 2018;3(2):11631175.

11. Kementrian Pertanian. Statistik Konsumsi Pangan. Jakarta: Pusat Data dan Sistem Informasi Pertanian Kementrian Pertanian. 2015.

12. Kurniawan JA, Anandito RBK, Siswanti S. Karakteristik fisik, kimia dan sensori cookies berbahan dasar tepung komposit uwi (Dioscorea alata), koro glinding (Phaseolus 
lunatus) dan tepung terigu. Jurnal Teknologi Hasil Pertanian. 2018;11(1):20-32.

13. Legowo, A. Analisis Pangan. Semarang: Badan Penerbit Universitas Diponegoro. 2005.

14. Liandani W, Zubaidah E. Formulasi pembuatan mie instan bekatul (kajian penambahan tepung bekatul terhadap karakteristik mie instan). Jurnal Pangan dan Agroindustri. 2014; 3(1):174-185.

15. Luthfianto D, Noviyanti RD, Kurniawati I. Karakterisasi kandungan zat gizi bekatul pada berbagai varietas beras di surakarta. The $6^{\text {th }}$ University Research Colloquium 2017 Universitas Muhammadiyah Magelang; 2017. P. 371-376.

16. Moore J, Luther M, Cheng Z, Yu L. Effects of baking conditions, dough fermentation, and bran particle size on antioxidant properties of whole-wheat pizza crusts. Journal of Agric Food Chem. 2009;57:832-839.

17. Muchsiri M. Pengaruh waktu blanching dan suhu pengeringan pada pembuatan tepung bekatul. Jurnal Penelitian Ilmu-ilmu Teknologi Pangan. 2014.3(1):17-27.

18. Mulyani T, Djajati S, Rahayu LD. Pembuatan cookies bekatul (kajian proporsi tepung bekatul dan tepung mocaf) dengan penambahan margarine. Jurnal Teknologi Pangan. 2016;9(2):1-8.

19. Pradipta IBYV, Putri WDR. Pengaruh proporsi tepung terigu dan tepung kacang hijau serta subtitusi dengan tepung bekatul dalam biskuit. Jurnal Pangan dan Agroindustri. 2014.3(3):793-802.

20. Purwanto A, Fajriyanti AN, D Wahyuningtyas D. Pengaruh jenis pelarut terhadap rendemen dan aktivitas antioksidan dalam ekstrak minyak bekatul padi (Rice Bran Oil). Journal of Chemical Engineering. 2014;13(1):29-34.

21. Rahmah A, Hamzah F, Rahmayuni R. Penggunaan tepung komposit dari terigu, pati sagu dan tepung jagung dalam pembuatan roti tawar. Jurnal Online Mahasiswa Fakultas Pertanian Universitas Riau. 2017;4(1):1-14.

22. Tamrin R, Pujilestari S. Karakteristik bubur bayi instan berbahan dasar tepung garut dan tepung kacang merah. Jurnal Konversi. 2016;5(2):49-58.

23. Wahjuningsih SB, Septiani AR, Haslina H. Organoleptik cereal dari tepung beras merah (Oryza nivara Linn.) dan tepung kacang merah (Phaseolus vulgaris Linn.). Jurnal Litbang Provinsi Jawa Tengah. 2018;16(2):131-142. 